\title{
Factors Affecting Loan Repayment Rate from ACSI among Smallholder Farmers: In the case of Habru District, Eastern Amara Regional State, Ethiopia
}

Andualem Kassegn ( $\sim$ andualemkassegn@gmail.com )

Woldia University

\section{Ebrahim Endris}

Woldia University

\section{Research}

Keywords: Smallholders, Defaulters, Non-defaulters, Loan, Tobit, Ethiopia

Posted Date: July 8th, 2021

DOI: https://doi.org/10.21203/rs.3.rs-684555/v1

License: (c) (i) This work is licensed under a Creative Commons Attribution 4.0 International License. Read Full License 


\section{Abstract}

This paper aims to examine factors affecting loan repayment rate from Amhara Credit and Saving Institutions (ACSI) among smallholder farmers in Habru district, Ethiopia. In this study, both primary and secondary data sources were used. The study employed a combination of multi-stage purposive and stratified sampling techniques in the selection of 384 borrowers from small-holder farmers in the study area. The Tobit model result found that a total of 10 out of the total 15 explanatory variables involved in the model were found to be statistically significant. According to the result demographic factors (age and household size), socio-economic factors (educational level, land size, livestock size, non-farm income, purpose of borrowing), and institutional factors (road distance, contact with development agents, training received on loan use) were among the factors that influenced loan repayment rate of small-holder borrowers in the study area. Education level, land size, livestock size in TLU, non-farm income, purpose of borrowing, contact with agricultural extension agents, and training received on loan use were found to determine loan repayment rate of borrowers positively and significantly, while age, family size, and road distance were found negatively and significantly determine loan repayment rate in the study area. Therefore, the overall result of this study underlined the great importance of the significant factors to profoundly achieve high repayment rate on borrowed funds from ACSI in the study area.

\section{Introduction}

Poverty alleviation has been of the key development challenges over the economies of most developing countries over the decades. Ethiopia, as a Least Developed Country (LDC), needs huge financial alternatives for rapid and sustainable development and improves the living standards of low-income small-holder farmers. Financial institutions ought to contribute to sustainable economic and financial systems development by offering access to credit for clients who are usually excluded from the formal banking system (Zerai \& Rani, 2012; Lopatta et al., 2017), are ways of achieving increased agricultural productivity to reduce poverty in Ethiopia (Brehanu \& Fufa, 2008; Million et al., 2014). As financial alternatives, Microfinance Institutions (MFIs) are not only allows people living in poverty rather they increase household incomes, savings, and consumption, education levels, and build assets to establish self-employment activities (Banerjee et al., 2014). MFIs are considered as a tool for poverty alleviation through improving access to finance and financial services (Kinde, 2012; Werema \& Opanga, 2016; Garomsa, 2017). Delivering productive, low cost, and efficient credit services and recovering a high percentage of loans granted are the ideal aims in rural finances (Wenner, 2015). The major objectives of MFIs are creating job opportunities, reducing poverty, empowering women, encouraging small, and petty trades (Kinde, 2012; Pasha\& Negese, 2014). Consequently, MFIs were established to fill the gap of scarce finance resources by providing funds to the poor and lower-income group to alleviating poverty and enhance their business activities (AfDB, 2012). The MFIs service consists of provision of microloans, micro-savings, micro-insurance service, money transfer, leasing and other relevant schemes to the target poor peoples who have been excluded by the conventional commercial banks due to lack of collateral requirements, information of asymmetric, and high transaction costs (Melkamu, 2012; Pasha and Negese, 2014; Melese \& Asfaw, 2020). Microfinance has become a major tools used to extend credit to many low income entrepreneurs in developing countries. The provision of microcredit services improves the latent capacity of the poor for entrepreneurship thus enabling their increased self-reliance, increasing their capacity to create more employment opportunities and ultimately enhancing household income and creating wealth (Allen et al., 2012).

According to Deribie et al. (2013) MFls are pivotal way outs from the vicious circle of poverty predominantly for the rural and urban poor, mainly in a country like Ethiopia where many people live below the absolute poverty line. MFIs in Ethiopia are playing an important role in poverty reduction strategies initiated by the government of Ethiopia. These institutions have a mission of creating and facilitating credit and other financial schemes to enhance self-employment opportunities and poverty reduction (Reta, 2011; Garomsa, 2017). Until the year 2016, there were about 35 MFIs formally established and providing microfinance activities in Ethiopia. Of these, Amhara Credit and Saving Institution (ACSI) is one of which supposed to provide microfinance services with people of the Amhara Regional State and beyond. Given the level of poverty in the region, ACSI's primary mission is to advance the economic condition of low income, productive poor people 
in the Amhara region principally through increased access to credit and saving services (ACSI, 2016). Access to credit can help rural poor economy through expanding the capacity of the smallholder farmers to meet their financial needs such as, the buy and utilized improved agricultural inputs which are not accessible from the farm. Access to rural credit may build the farmers' capacity to modern agricultural technologies that increase the income of the smallholder farmers and halts poverty cycle (Anyiro \& Oriaku, 2011). Besides, revealed that microfinance credit has allowed the customers to generate income that might be spent on better services, which could improve the living standard of clients. The financial institutions are the backbone of the smallholder farmers when compared to informal sources due to loan adequacy and low-interest charge. More importantly, credit is required by smallholder farmers to achieve total transformation from the level of subsistence orientation to market orientation. This is based on the result that credit determines farmers' accessibility to other resources (Sunday \& Anthonia, 2017).

There is no doubt about the crucial roles of credit in economic development. While the increasing default rate is one of the major problems of the lending institutions (Mohammad, 2009). Loan repayment problem discourages rural finance institutions from encouraging and extending credit (Melese \& Asfaw, 2020). If the loan funds in an economy are not repaid, it limits the recovering of the funds is reduced by the amount of classified loans which may lead to economic stagnation. The central trouble of the poor performance of financial institutions in many developing countries is the high rate of nonrepayment of the loan (Reta, 2011). It is important to state that the borrowers alone cannot be held responsible for failure to pay the loan as it is imperative to inspect the level to which both borrowers and leaders bear by the loan agreement and the nature of the duties, responsibilities, and duties of both parties as revealed in the plan of the credit program (Afolabi, 2010). The poor loan controlling system causes serious challenge and default problems to most MFIs. Loan defaults continue to be a major challenge that confronts financial institutions in developing countries and this impedes their potential role in sustainable development (Baidoo et al., 2020). Loan default has been given more prominence in policy discourse and attracted attention of researchers (Asiama \& Amoah, 2019). Therefore, analyzing factors influencing loan repayment rate in the case of ACSI Habru branch has become rationale of this study. According to Werema \& Opanga (2016) there are several factors that are influencing loan repayment performance among MFIs. The issue of loan repayment is vigorous while providing credit facilities to the poor to release financial constraints and to alleviate poverty. It is a crucial issue for the MFIs to assess the problems of loan recovery of the borrowers and the influencing factors for low loan repayment rate to advance the financial sustainability and profitability of their respective institutions by maintaining a strong credit risk management systems (Ibtissem \& Bouri, 2013).

\subsection{Statement of the Problem}

The phenomenon of default on borrowed funds is still one of the critical problems faced by financial institutions in developing countries in their attempt to expand their services and reach a large number of clients. Despite the contribution of MFIs in poverty reduction, job creation, and sustainable economic growth of both in a developed and developing nation, there are numerous challenges face in their activities. The government and MFIs work more cooperatively towards minimizing fiscal hindrances while innovating and expanding many alternatives for poor individuals to access credit (Tarekegn \& Molla, 2018). The most common and often the most serious susceptibility in MFls is that they may not obtain its money back from borrowers. Loan default may also deny new applicants access to credit service as the MFIs management augment problems in direct proportion to the increasing default problem. Later, low repayment rate discourages MFIs from refinancing the defaulting members and they are not viable because of default problem, borrowers will also not have access to loan and suffer from poverty, which affects the development of the country as a whole (Reta, 2011; Sileshi et al., 2012; Gebeyehu et al., 2013). One way or another, the number of defaulters have been challenging MFI's objectives by retaining a large amount of loan and hinder efforts to combat poverty and the realization of sustainability of MFIs (Pasha\& Negese, 2014). For example, in Ethiopia, the trend of loan recovery performance in the financial industry during the following period (2015/2016-2016/2017), loan collected decreased from $40.6 \%$ to $20.6 \%$. This indicates that the customers' profitability is decreased that hampered their paying back ability (Kebede, 2018). While high repayment rate is 
related to the advantages of both MFIs and borrowers (Tarekegn \& Molla, 2018). High repayment rate also allows the clients to obtain a higher amount of loan in the next time (Reta, 2011).

However, according to Sileshi et al. (2012) the loan repayment is influenced both directly and indirectly by various factors such as Government policies, demography, institutional, cultural, and environmental factors. Several researchers have put forward the benefits, problems, access, and role of credit service for increased efficiency in production whereas rapid repayment of credit is essential for upright creditworthiness. Therefore, the incapability of borrowers to repay the amount of loans collected is vital for the long-term sustenance of credit institutions. As a result, various studies have tried to study the loan repayment performance of many socio-economic groups.

According to Garomsa (2017) on his study factors affecting loan repayment revealed that variables including sex, income from other sources, monitoring utilization of other members in a group, credit timeliness, repayment time suitability, repayment trend monthly, and training adequacy are found to be significant factors that affect loan repayment rate of the borrowers. On the other study, income, farming experience, loan application cost, interest charge, loan size, security, and number of installments were found to be pivotal roles in loan repayment rate of the borrowers (Sunday \& Anthonia, 2017). Jote (2018) also found that variables like the method of lending, educational level, family size, nearness of borrower's residence to the institutions, income from activities financed by loan, and training were found to be significant factors influenced loan repayment performance of borrowers. According to Sileshi (2014) and Abera \& Asfaw (2019) the major socio-economic factors that influence credit repayment are age of household head, education level, gender of household head, family size, farm size, loan size, annual farm revenue, loan diversion, livestock ownership, frequency of contact with extension agent, group effect, and residence of borrowers from the lending institution. The study of Yibrie \& Ramakrishna (2017) that was conducted at ACSI by employing multinomial logit model found that out of fourteen variables hypothesized to affect loan repayment performance of borrowers, eight variables (age, sex, education level, interest rate, loan size, loan tenure, training, and monthly sale) were found to be statistically significant. Similarly, Gebeyehu et al. (2013), Alemayehu \& Lemma (2014), Abu et al. (2017), Garomsa (2017), Ume et al. (2018), and Yimer (2019) took merely farmer borrowers as participants of their study from different MFIs and settings, studies are also different in terms of location and culture from the setting where the current study was conducted have found different results regarding factors affecting the capacity of borrower's to repay their loan on time.

Therefore, the study on factors affecting loan repayment performance is not a new research area while the result of the studies are different and debatable among different researchers at different study areas as we clearly mentioned above. The results showed that there is inconsistency regarding factors affecting loan repayment performance of small-holder farmers. As previous studies found there are host of factors related to small-holder borrowers demographic, socioeconomic, institutional, and cultural that could explain the differences in the rate of default on borrowed funds. However, in this study area, there was no empirical study so far that has examined and answered the question of what are the deriving factors of low loan repayment rate among small-holder farmers at ACSI branch of Habru district. Despite the efforts made by the institutions to ensure that all loans to be recovered on time, a substantial amount of loans remain unrecovered. This low rate of loan repayment performance of these small-holder farmers will adversely affects the borrowers themselves and the institution efficiency and sustainability. Therefore, to maintain the sustainability of the institution and ensure the substantial advantage of borrowers from the credit access, examining factors affecting loan repayment rate is essential. The specific objectives of this study were to examine factors affecting loan repayment rate of small-holder farmers and provide possible solutions for the institutions to minimize the default rate of borrowers based on the recognized factors.

\section{The Theoretical Literature}

A credit default signifies the financial disappointment of an entity (a person or a company). A theory of credit default should therefore signify a logical empathetic of the reasons which directly lead to the effects which are related with credit

Page $4 / 27$ 
defaults. Such a theory is required to deliver direct causal links between macroeconomic causes of altering financial environment and their microeconomic effects on changing personal or corporate financial circumstances, leading to possible credit defaults. Most present theories of credit default do not meet this causal requirement (Jarrow \& Protter, 2004). In reality a credit default event for a secured loan is a sequence of two temporally disconnected events: a delinquency event followed by an insolvency event. If a borrower always make full loan payments by due dates, insolvency is irrelevant (Keenan, 1999). Insolvency alone cannot be a reason for a credit default. This is because, the assets of an entity or individual is not easily visible at any given time, even to insiders, mainly if the assets are comprised from intangible assets. Only a delinquency is supposed to cause a net equity position to be evaluated, leading to a conceivable conclusion of insolvency and therefore credit default.

Default on borrowed assets could be voluntary and involuntary. Involuntary default on borrowed assets could emerge from troublesome conditions that may influence the capacity of the borrower to repay. Then again, vulnerary default, whereby a borrower doesn't repay regardless of whether he/she can do. The real definition of a default as a delinquency with a time lag is therefore simply to deliver an early acknowledgement of possible loss and the time lag may differ from country to country due to cultural and legal variations. By and large, the lender probably won't have full information about the borrower characteristics while making loaning regarding whether the borrower is a high risk or low risk (adverse selection) and probably won't have the option to screen the borrower's activities concerning the utilization of the borrower funds (moral hazard).

Stigliz and Weiss (1981) laid the theoretical establishments of adverse selection under the two main assumptions: The borrower can't recognize between low risk and high risk borrowers and loan agreements are liable to limited liability. Under the limited liability assumption, borrowers are not obliged to reply if the task returns are not exactly the obligation commitments. This assumption limits the investigation of credit repayment risk to just involuntary default. However, the distribution of profits from the utilization of borrowed funds and the capacity to repay likewise relies upon the borrower's activities and limited obligation would clearly build default risks. Monitoring and authorization activities increase loaning expenses to budgetary organizations making loaning to the small and dispersed clients such as small-scale farmers unprofitable. However, small scale farmers are profoundly obliged by absence of adequate working funding to utilize new technologies. Therefore, access to credit for farmers is one of the basic institutional arrangement fundamental for development. As of late, group loaning approach instead of the arrangement of credit to individual farmers directly is progressively being embraced by financial institutions to asymmetric information problems mentioned above. Subsequently, in case of default, the group instead of individual farmers is made at accountable.

However, the probability of default for any specific borrower increases as the amount borrowed increases (Freimer \& Gordon, 1965; Dwight, 1971). In group lending, however, the insurance (collateral) is the group itself, not a physical asset and the group uses social sanctions against a defaulter. Regardless of whether group lending improves loan repayment or not is as yet controversial (Huppi \& Feder, 1990; Zeller, 1998). Therefore, the wonder of default on borrowed funds is as yet one of the basic issues faced by financial (formal or semi-formal) institutions in less developed countries in their endeavor to expand their services and arrive at huge number of clients. A host of factors associated with socio-economic and institutional characteristics of the households could clarify the distinctions in the rate of default on borrowed funds. Distinguishing those factors that are critical determinants of rate of repayment of loans is significant for the plan and execution of loaning policies pointed toward improving default risks.

The microfinances' credit rationing behavior may theoretically be influenced by a number of factors which include the borrower's observable characteristics (age, gender, family size, education level, wealth, household income, asset values, experiences, and credit history), firm characteristics (business experience, risk profile, and earnings), and loan characteristics (amount demanded, loan maturity, collateral offered, interest rate, and loan size ) (Lapar \& Graham, 1988). These observable socio-economic characteristics of the borrower are argued in the theoretical literature to reduce the borrower's probability of being credit rationed (Nuryartono et al., 2005; Okurut et al., 2006). According to 
(Olokoyo, 2011) loan pricing theory, therefore, setting determinants for loan repayment is very crucial to determine the borrowers' capacity to repay loans. Apart from economic indicators, there exists other social factors from the borrowers that could as well predict their potential to default on loan repayment. As a result, microfinance institutions are integrating both social and economic variables in lending assessment model to improve the loan repayment performance. According to the theory of Becker (1993), Kraiger et al. (1993), and Ployhart \& Moliterno (2011) individuals or groups with experience and high education level perform better in executing relevant tasks and show significantly higher repayment rates.

\section{Research Methodology}

\subsection{Description of the study area}

The research was confined in Habru districts of North Wollo Zone of Ethiopia. It is located $491 \mathrm{~km}$ in North of Addis Ababa. It is one of largest district in the zone with total landmass coverage of 1,239.79 square kilometers. Habru is identified as the most drought prone and food insecure district in the Amhara Region since its economy is erratic rain feed based livelihood system. According to Habru District Chief Administration Office (HDCAO, 2020), the district has a total population of 243,572 of whom 123,286 are men and 120,286 are women. The district has 35 rural and 2 urban kebeles. The district is bordered on the south by the Mille River which separates it from the South Wollo Zone(Ambasel district), on the west by Guba Lafto, on the north by the Alewuha River which separates it from Kobo, and on the east by the Afar Region.

According to the information of Habru District Agricultural and Rural Development Office (HDARDO, 2020), the district lies at an altitude of $1430 \mathrm{~m}$ up to $2800 \mathrm{~m}$ above sea level and it receives an annual rainfall of ranges from $750 \mathrm{ml}$ up to $1000 \mathrm{~mm}$ with an average temperature of $22^{\circ} \mathrm{C}$. The climatic condition of the study area is weynadega $40 \%$, dega $3.5 \%$ and kola $56.5 \%$. It has four types of soil known as Chronic, Eutric, Xena, Classic and Cambisols. Mixed farming (crop production and livestock rearing) is the predominant sources of livelihood for the majority of the population in the area. Teff and Sorghum are the main dominant crops grown in the district.

\subsection{Data sources and collection methods}

The primary data was collected from the small-holder farmers who have received formal credit service (both defaulters and non-defaulters) from ACSI in the district directly through interview scheduled. Substantial primary data were also collected from the branch manager, loan officers, and audit officers of ACSI Habru branch through interview to know the status of portfolio quality of the branch and collect additional qualitative information. The questionnaire consisted of a wide range of questions on the demographic, institutional, socio-economic, and cultural characteristics of the sample respondents. The questionnaire was created and pre-tested to assess for consistency, lucidity and to keep away from duplication and to appraise the time prerequisite during data collection. Proper preparing and field practice were given to the enumerators to build up their comprehension concerning the targets of the study, the content of the survey, how to move toward the respondents, and conduct the interview timely.

\subsection{Sampling techniques and sample size determination}

Sample households were selected by using a multi-stage purposive and stratified sampling techniques. In the first stage Habru district is selected purposively. This is because, there was no scientific empirical study that has been conducted regarding loan repayment performance of small-holder clients of ACSI in the study area. Besides, ACSI branch in the study area has low loan recovery rate as compared to other branches of ACSI in North Wollo Zone. In the second stage, from a total of 35 farmers' associations (kebeles) found in the district, five farmers' associations (kebeles) namely Bohoro, Kule, Abiotfire, Anto, and Abuare were-purposively selected because they are the leading user of credit with long years of experience and their high default status. 
In the third stage, the list of the names of farmers who have obtained loan from ACSI were recorded from the entire five kebeles from who received loans in 2020 fiscal year. At the outset, the respondents were stratified into two categories, i.e. defaulters and non-defaulters. All borrowers from all selected kebeles who have repaid their loans on the due date were classified as non-defaulters while those who haven't repaid their loan on the due date were classified as defaulters. Finally, a total of 384 (163 defaulters and 221 non-defaulters) representative borrowers of small-holder farmers were randomly selected from each stratum using relative proportionate allocation to the percentage of the total population from the five selected kebeles of the district. To obtain a representative sample size, the study employed Cochran's (1963) sample size determination formula given as follow (Eq. 1). This study used a $95 \%$ confidence interval $(Z=1.96)$ for a two-tail test, and assuming that $P=0.1$, with an allowable error of $5 \%$. Therefore, based on this formula, the sample size was 384 .

$$
\mathrm{n}=\frac{z^{2} p \cdot q}{d^{2}}
$$

$\mathrm{n}=$ Sample size $\mathrm{Z}$ = Statistical certainty, related to the error risk, equals 1.96 for an error risk of $5 \%$ level of significance

$\mathrm{p}=$ Small-holder farmers who may access loan from ACSI

$q=$ The weight variable and is computed as 1-p

$d=$ Desired precision or margin of error, expressed as a fraction of 0.05

To determine sample size from each stratum, the following sample size determination formula has been used:

$$
\mathrm{n}_{\mathrm{h}}=\frac{\mathrm{Nh}}{\mathrm{Ns}} *_{\mathrm{n}}
$$

Where: $\mathrm{nh}=$ sample size from each stratum, $\mathrm{Nh}=$ Total population in each stratum, Ns=Total population of the sum of strata for study and $n=$ Total sample size from the study population.

Lastly, representative samples were selected randomly from sampled kebeles based on proportional to sample size.

\subsection{Method of data analysis}

The empirical data were analyzed using both descriptive and econometric methods. STATA software (Version 14) was employed for the analysis of the data.

\subsubsection{Descriptive statistics}

Descriptive statistics were used to describe the general characteristics of the database using basic statistics such as mean, standard deviations, numbers, and percentages to investigate the relative importance of the determinant variables that influenced the loan repayment rate of small-holder farmers. On the top of this, this study also used a t-test and chi-square test to test the mean difference of the continuous and discrete explanatory variables with that of the dependent variable, respectively.

\subsubsection{Analytical method}


In finance, a default occurs when a debtor fails to make the required payment on a timely basis or to comply with other conditions of an obligation or agreement. Default may occur if the debtor is either unwilling or unable to pay their debt. In this situation, there are degrees and intensities of defaulting. This perspective indicates that Tobit estimation should be adopted (Tobin, 1958). This is because, Tobit model is appropriate for modelling both the probability (defaulted or has not defaulted) and intensity (degree of loan recovery) of borrowing fund which is censored at the lower limit of zero (Gujarati, 2007). Tobit is an extension of the Probit model and it is one approach for dealing with the problem of censored data (Johnston and Dinardo, 1997). The Tobit model allows us to estimate the quantity repaid together with the likelihood of repayment using the same covariates (Wooldridge, 2016). While the use of a binary choice variable as a dependent variable may not capture intensity of loan repayment (Baidu-Forson, 1999; Brett, 2004). Lynne el al. (1988) also pointed out the possible loss of information if a binary variable is used as the dependent variable.

Besides, the use of linear probability model (LPM) is computationally and conceptually simpler and easier to use than the binary choice models, depends on the use of ordinary least squares (OLS) approach, application of OLS to censored model however, inherently produces a heteroscedastic disturbance term and as a result, the standard deviations of the estimates are biased. Therefore, to overcome these inadequacies and problems the use of Tobit estimation method (Tobin, 1956; Tobin, 1958; McDonald \& Moffit, 1980) has been proposed for analyzing both the probability and intensity of loan repayment where the dependent variable is continuous with a zero limit. Kim \& Maddala (1992) applied the model in estimating and specifying models of dividend behavior based on censored Panel Data. Currently, therefore, the utilization of Tobit models to examine censored and limited dependent variables has gotten progressively normal in applied social science research in recent decades (Smith \& Brame, 2003). There were several situations where the variable to be modelled was limited in its range. Because of the restrictions placed on the values taken by the regressand, such models can be called limited dependent variable regression models.

While when information on the regressand is available for some observations, using Ordinary Least Squares (OLS) may result in biased and inconsistent parameter estimates, even asymptotically. In OLS models, the bias arises from the fact that, if we consider only the observable or $n_{1}$ observations (that is, only observations for which the values of the dependent variable are observed) and omit the others, there is no guarantee that the estimated value of the error terms, $\left(E\left(u_{i}\right)\right.$, will be necessarily zero. Without $\mathrm{E}\left(\mathrm{u}_{\mathrm{i}}\right)=0$, it cannot be guaranteed that the OLS estimates will be unbiased. In addition, as compared to the Probit model, under the Tobit model the value of $y^{\star}$ is known when $y^{\star}>0$. However, in the Probit model, the value of $y^{*}$ is unknown, but there is information indicating whether it is greater than $y^{*}>0$. Therefore, the Tobit model has more information than the probit model. Estimates obtained under the Tobit model are more efficient compared to those obtained by the Probit model (Schervish, 1995). The most important element of the model is its ability to solve problems of imperfect data used in the analysis. It improves the results obtained from the regression analysis hence enhances the establishment of accurate relationships between variables of concern.

In this study, the value of the dependent variable is loan repayment rate. The value of the variable has been computed as the rate of the amount of loan repaid to the total amount borrowed from ACSI sources of credit. In this way, the estimation of the dependent variable reaches somewhere in the range of 0 and 1. In the Tobit model, the dependent variable of the regression often has a lower or upper limit; it takes on the limiting value for a number of observations and takes a wide range of values for the remaining observations (Amemiya, 1973). In this case, therefore for this study, a two limit Tobit model has been picked as a more fitting econometric model (Rosett \& Nelson, 1975). This study used the two limit Tobit economic model to examine factors affecting probability of loan repayment and the actual performance of loan repayment in the study area.

\subsection{Definition of variables and working hypothesis}




\subsubsection{Dependent variable}

The dependent variable for the Tobit model for this investigation is characterized as the rate of formal credit paid by borrowers during the predefined repayment period, which is a continuous variable, determined from the aggregate sum of loan that an individual took. Its value ranges between 0 and 1 . The amount of money they borrowed according to acknowledge plans are considered as complete defaulters (i.e. the value of repayment ratio, in this case, is zero) and the borrowers who had repaid completely the sum they acquired are considered as non-defaulters and assume a value of one.

\subsubsection{Explanatory variables}

Based on the literature review, economic theories and observations on the subject, the loan repayment rate of a smallholder farmers could be affected by demographic, socioeconomic, institutional, and cultural factors that are expected to be feasible and relevant in the loan repayment system of the branch. Table (1) illustrated the description of the explanatory variables selected for this study and their likely influence on the loan repayment rate of borrows. The following dependent and independent variables were identified to discriminate between non-defaulters and defaulter small-holder farmers in the study area.

\section{Results And Discussions}

This chapter includes two sub-headings. In the first section, results of descriptive statistics were presented and discussed. Under descriptive statistics, important characteristics of the small-holder farmers were illustrated with appropriate statistical tools like mean, standard deviations, numbers, and percentages. The second sub-heading presents econometric results which include estimates of the Tobit Model and the influential factors on the probability of being non-defaulter and marginal effects.

\subsection{Descriptive statistical results}

\subsubsection{A comparison of characteristics among defaulters and non- defaulters}

Both continuous and discrete variables were used to describe the sample households included in this study. As already described above, various observable characteristics were used to describe both defaulter and non-defaulter smallholder farmers in the study area. Hence, this section mainly discussed small-holder farmers characteristics, which describe loan repayment rate significantly, i.e., age, education level, family size, land size, livestock size, non-farm income, road distance, contact to office of agricultural extension agents, and training of sample household's as well. Table (2) and (3) illustrated the descriptive analysis of sample respondents for continuous and discrete variables, respectively.

Table 2

A demographic, socio-economic, and institutional characteristics among defaulters and non-defaulters for the entire respondent (for continuous variables) 


\begin{tabular}{|c|c|c|c|c|c|c|c|}
\hline \multirow[t]{2}{*}{ Variable } & \multicolumn{2}{|c|}{ Defaulter $(\mathrm{N}=163)$} & \multirow{2}{*}{$\begin{array}{l}\text { Non-defaulter } \\
\text { Mean }\end{array}$} & $(N=221)$ & \multicolumn{2}{|c|}{ Total $(\mathrm{N}=384)$} & \multirow[b]{2}{*}{ t-value } \\
\hline & Mean & Std.dev & & Std.dev & Mean & Std.dev & \\
\hline AGE & 52. 13 & 10.62 & 42.67 & 10.59 & 47.40 & 10.61 & $8.64^{\star \star \star}$ \\
\hline FAMSIZE & 4.55 & 1.53 & 4.20 & 1.24 & 4.38 & 1.39 & $2.45^{\star \star}$ \\
\hline EDULVL & 2.48 & 1.50 & 6.08 & 2.13 & 4.28 & 2.57 & $-18.44 * \star *$ \\
\hline LNDSIZ & .44 & .19 & .93 & .22 & 0.72 & 0.21 & $-22.93^{\star * \star}$ \\
\hline LIVSTKNO & 1.86 & 1.46 & 4.29 & 2.08 & 3.08 & 1.77 & $-12.78^{\star \star \star}$ \\
\hline RODDIST & 2.18 & .65 & 1.10 & .34 & 1.64 & 0.50 & $21.08^{\star \star \star}$ \\
\hline CWDAGE & 3.54 & 1.80 & 5.39 & 2.55 & 4.47 & 2.18 & $-7.94 * \star \star$ \\
\hline LNAMNT & 6379.96 & 6401.28 & 5743.87 & 3549.54 & 6061.92 & 4975.41 & 1.24 \\
\hline EXPSOF & .37 & .49 & .33 & .47 & 0.35 & 0.96 & 0.98 \\
\hline \multicolumn{8}{|c|}{ 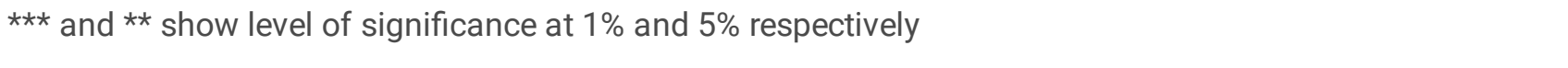 } \\
\hline
\end{tabular}

As Table (2) illustrated, seven continuous variables considered among defaulters and non-defaulters were found to be significant. These were age, family size, education level, land size, livestock size in (TLU), road distance, and contact with development agents. While those found not to be significant were the amount of loan received and expenditure on social festivals. Accordingly, the significant variables were discussed one by one below.

Age is one of the main factor that determine the loan repayment rate of borrowers. The average age of the household heads for all the respondents was 47.40 years, while independently the average years of respondents were 52.13 and 42.67 for defaulters and non-defaulter respectively. The mean age of non-defaulter borrowers (42.67) was found to be significantly less than the mean age of defaulter borrowers (52.13). This indicates that there was significant mean difference between the average years of the two groups at $1 \%$ level of probability (Table 2). This implies, in this study, loan repayment rate is dependent on the age of the borrowers.

Family size refers to the number of people living in a family that directly or indirectly affects the borrowed loan. The average family size of the sample households was 4.38 persons, which is below the average family size per households in our country. Table (2) revealed that there was a significant difference between defaulters and non-defaulters borrowers at $5 \%$ in terms of the number of family members in a household. The mean family size of defaulter borrowers (4.55) was significantly greater than that of non-defaulters (4.20). This indicates that defaulter borrowers do have larger family size than non-defaulters. Therefore, loan repayment rate is related to the family size of borrowers. The larger the family size, the less likely the borrowers to repay their loans.

Education is a very important determining factor for loan repayment rate of small-holder farmers. According to the survey result, the average year of formal schooling of the sampled respondents was grade 4.28. The mean grade attained for defaulters and non-defaulter borrowers were 2.48 and 6.08 grades, respectively. When we compare the mean educational level of defaulters with non-defaulters, the non-defaulters have more education than their counterparts. The result showed that there was a statistically significant mean difference between the defaulter and non-defaulter at $1 \%$ regarding educational level of household heads (Table 2). This show as higher educational level enables borrowers to realize relevant information, go on business records, manage the loan properly, and make the right business decisions that enable them as being non-defaulters. 
Land is by far the most important resource in agriculture. Relatively, a farmer with more hectares of land is better off in loan repayment performance. As witnessed by the survey results, the mean land size of defaulters and non-defaulters were found to be 0.44 and 0.93 hectares, respectively. As Table (2) illustrated, the mean loan size of defaulters is less than the mean loan size of non-defaulters. This implies that there was a positive relationship between land size and loan repayment rate and found to be significant at $1 \%$ level of significance. The possible reason for this was that small-holder farmers with larger farm sizes were more likely and capable to repay their loan on time.-

In this study, based on Storck et al. (1991) standard conversion factors, the livestock population number was converted into Tropical Livestock Unit (TLU), to facilitate comparison between the defaulters and non-defaulters. On average, a sample household heads had 3.08 TLU with a standard deviation of 1.77. As Table (2) illustrated, non-defaulters owned large number of livestock (on average 4.29 TLU) as compared to the defaulters (on average 1.86 TLU) with mean difference of 2.43 TLU and significant at $1 \%$ level significance. This implies that livestock ownership was positively associated with the repayment performance of the households.

In this study, the road distance in kilometers that the borrowers travelled on foot to get to a market center was assessed (distance between their residence and the market center). The loan repayment rate based on borrowers road distance to the market center was tested using t-test. Accordingly, borrowers living near the market center have a location advantage and can easily access the market center than those who live in more distant locations from the market center. The mean distance of non-defaulter borrowers (1.10) was found to be significantly less than defaulter borrowers (2.18). The t-test showed that there was statistically significant difference between defaulter and non-defaulter borrowers' interns of road distance to the nearest market at $1 \%$ probability level (Table 2). This leads to the conclusion that there was a significant relationship between loan repayment rate of borrowers and road distance from the market center.

The number contact years with development agents varied among the sample borrowers. Non-defaulters have participated on average for a higher number of years 5.39 as compared to the defaulters who have participated on average for 3.54 years (Table 2). The mean difference between the two groups was significant at $1 \%$ level of significance. That is, a smallholder farmers experience in agricultural extension services has a pivotal role in loan repayment performance.

Table 3

Demographic, socio-economic, and institutional characteristics among defaulters and non-defaulters for the entire respondent (for discrete variables) 


\begin{tabular}{|c|c|c|c|c|c|c|c|c|}
\hline \multirow{3}{*}{ Variables } & \multirow{3}{*}{ Category } & \multicolumn{2}{|c|}{ Defaulter } & \multicolumn{2}{|c|}{ Non-defaulter } & \multicolumn{2}{|c|}{ Total } & \multirow{2}{*}{$\begin{array}{l}\text { Chi-square } \\
\text { Test } \\
\chi^{2} \text {-value }\end{array}$} \\
\hline & & No. & $\%$ & No. & $\%$ & No. & $\%$ & \\
\hline & & & & & & & & Value \\
\hline \multirow[t]{2}{*}{ SEX } & Male & 100 & 61 & 135 & 61 & 235 & 61 & 1.36 \\
\hline & Female & 63 & 39 & 86 & 39 & 149 & 39 & \\
\hline \multirow[t]{2}{*}{ NONFIN } & Yes & 64 & 39 & 170 & 77 & 234 & 61 & \multirow[t]{2}{*}{$55.89 * * *$} \\
\hline & No & 99 & 61 & 51 & 23 & 150 & 39 & \\
\hline \multirow{2}{*}{ PURBOR } & Productive & 59 & 36 & 153 & 69 & 212 & 55 & \multirow[t]{2}{*}{ 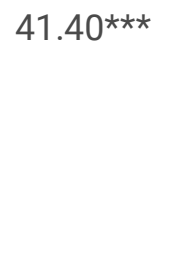 } \\
\hline & Non-productive & 104 & 64 & 68 & 31 & 172 & 45 & \\
\hline \multirow[t]{2}{*}{ CRDSER } & ACSI credit source & 92 & 56 & 108 & 49 & 200 & 52 & \multirow[t]{2}{*}{2.16} \\
\hline & informal credit & 71 & 44 & 113 & 51 & 184 & 48 & \\
\hline \multirow{2}{*}{ TRALU } & Received & 11 & 7 & 211 & 95 & 222 & 58 & \multirow[t]{2}{*}{ 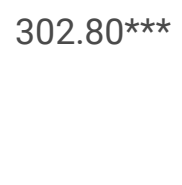 } \\
\hline & Not received & 152 & 93 & 10 & 5 & 162 & 42 & \\
\hline \multirow[b]{2}{*}{ AVABUIF } & Yes & 139 & 85 & 186 & 184 & 325 & 85 & \multirow[t]{2}{*}{0.09} \\
\hline & No & 24 & 15 & 35 & 16 & 59 & 15 & \\
\hline
\end{tabular}


*show level of significance at $1 \%$ respectively

Source: Own survey result (2021)

Table (3) illustrated the descriptive statistics of demographic, socio-economic, and institutional characteristics among defaulters and non-defaulters (for discrete variables). The result revealed that non-farm income, purpose of borrowing, training on loan use had a significant relationship with loan repayment rate at $1 \%$ level of probability, while other variables such as sex, credit service, and availability of information did not have a significant relationship with loan repayment rate.

As the result revealed that, about $61 \%$ of the sampled household heads reported that at least one of their family member was engaged in non-farm activities that helped them to earn additional income. The survey result also indicated that a larger proportion of the non-defaulter households (77.00\%) engaged in non-farm activities as compared to the defaulter households $(23.00 \%)$. The Chi-square test indicated that there was an efficient association between loan repayment rate of borrowers and non-farm income at $1 \%$ level of significance (Table 3).

Purpose of borrowing is another economic factor that was significantly affected loan repayment rate of small-holder farmers at less than 1\% probability level. As shown in Table (3), 55\% (212) of the respondents used their loan for productive purposes, whereas 45\% (172) did not use their loan for productive purposes. The Chi-square test shows that there was a statistically significant difference between defaulters and non- defaulters in terms of the purpose of borrowing in the study area.

Training received on loan use is very important to run the business effectively and efficiently. This is because, training enables borrowers to increase their knowledge as well as improves their skills. This study showed that 58\% (222) of the respondents received training on credit utilization and loan repayment activities, like how they use the loan effectively and efficiently, whereas 48\% (162) did not take any training. From the untrained borrowers $93 \%$ (152) and 10\% (5) were defaulters and non-defaulters, respectively. The Chi-square test shows that there was a statistically significant difference at $1 \%$ between defaulters and non-defaulters in terms of training on loan use in the study area (Table 3 ). This implies that non-defaulters are more trained than defaulters on credit terms and loan utilization.

\subsection{Econometric results}

In this section econometric analysis was carried out to identify the significant factors that influence the loan repayment rate of small-holder farmers in the study area. As explained in the methodology section, a Tobit model was employed to estimate the effects of hypothesized explanatory variables on the loan repayment rate of smallholder farmers. To this effect, before carrying out Tobit regression, the key assumptions of the Tobit regression model were checked and found none of the assumptions was violated. After checking none of the assumptions of the Tobit model was violated, therefore, the analysis was carried out and the result was presented here below. Based on the economic theory and the existing data, the explanatory variables selected for this study were broadly categorized under demographic, socio-economic, institutional and cultural related factors. Table (4), in this regard, illustrated the two limit Tobit model estimates that borrowers of ACSI Habru branch with the specified variables, the borrowers have to repay the received loans as per to the schedule and how the influential factors are significantly related with borrowers' loan repayment rate category in the output.

\subsubsection{Determinants of loan repayment rate at ACSI branch in Habru district}


Table (4) illustrated the Tobit regression model output that indicated significant factors that affecting loan repayment rate of the respondents in the study area. The two limit Tobit result found that 10 variables from a total of 15 variables that are considered in the econometric model significantly impact the probability of being non-defaulter and the intensity of loan recovery among borrowers of the entire sample. The log-likelihood estimates of the Tobit regression model designate that age of the borrowers, family size, education level, land size, livestock size, non-farm income, purpose of borrowing, road distance, contact years of the farm household heads with extension agents, training on loan use before taking loans were important factors influencing the loan repayment rate of smallholder farmers in the study area. The remaining variables (Sex, credit source, loan amount, availability of business information, and expenditure on the social festivals) were found to have an insignificant effect on loan repayment rate of smallholder farmers. Therefore, this discussion exclusively focused on the significant factors that influence the loan repayment rate of small-holder farmers in the study area at ACSI branch.

Table 4

Two-limit Tobit model estimates, marginal effect of factors influencing loan-repayment and probability of being nondefaulter 


\begin{tabular}{|c|c|c|c|c|c|c|c|c|}
\hline Variables & Coefficients & Std. Err & $\mathrm{T}$ & $p>t$ & $\begin{array}{l}\text { Test } \\
\text { Decision }\end{array}$ & $\begin{array}{l}\text { Probability } \\
\text { Being } \\
\text { Non- } \\
\text { Defaulters }\end{array}$ & $\begin{array}{l}\text { Conditional } \\
\text { on Being } \\
\text { Uncensored }\end{array}$ & $\begin{array}{l}\text { Unconditional } \\
\text { Expected } \\
\text { Value }\end{array}$ \\
\hline AGE & -.002709 & .0013617 & -1.99 & $\underset{* \star}{0.047}$ & Reject & -.0007545 & -.0017619 & -.0017289 \\
\hline SEX & -.0014072 & .0107877 & -0.13 & 0.896 & $\begin{array}{l}\text { Failed to } \\
\text { reject }\end{array}$ & -.0003919 & -.0009153 & -.0008981 \\
\hline FAMSIZE & -.0189528 & .0112956 & -1.68 & $\begin{array}{l}0.094 \\
\star\end{array}$ & Reject & -.0052788 & -.0123269 & -.0120956 \\
\hline EDULVL & .0415756 & .0066905 & 6.21 & $0.000 * \star \star$ & Reject & .0115797 & .0270409 & .0265334 \\
\hline LNDSIZ & .3836882 & .0617689 & 6.21 & $0.000 * * *$ & Reject & .1068654 & .2495515 & .2448682 \\
\hline LIVSTKNO & .0123048 & .0072162 & 1.71 & $\begin{array}{l}0.089 \\
\star\end{array}$ & Reject & .0034272 & .0080031 & .0078529 \\
\hline NONFIN & .1165985 & .0338988 & 3.44 & $0.001 * * *$ & Reject & .0324752 & .0758359 & .0744127 \\
\hline PURBOR & .0993988 & .0330549 & 3.01 & $0.003^{\star \star *}$ & Reject & .0276847 & .0646492 & .0634359 \\
\hline RODDIST & -.2153325 & .0326892 & -6.59 & $0.000 * * *$ & Reject & -.0599747 & -.1400526 & -.1374243 \\
\hline CWDAGE & .0122885 & .0058521 & 2.10 & $0.036 * \star$ & Reject & .0034226 & .0079925 & .0078425 \\
\hline CRDSER & -.0265873 & .0338488 & -0.79 & 0.433 & $\begin{array}{l}\text { Failed to } \\
\text { reject }\end{array}$ & -.0074051 & -.0172924 & -.0169679 \\
\hline LNAMNT & $1.16 \mathrm{e}-06$ & $3.85 e-06$ & 0.30 & 0.764 & $\begin{array}{l}\text { Failed to } \\
\text { reject }\end{array}$ & $3.22 \mathrm{e}-07$ & $7.53 e-07$ & $7.39 \mathrm{e}-07$ \\
\hline TRALU & .6008763 & .0498866 & 12.04 & $0.000 * * *$ & Reject & .167357 & .390811 & .3834768 \\
\hline AVABUIF & -.0083677 & .0419044 & -0.20 & 0.842 & $\begin{array}{l}\text { Failed to } \\
\text { reject }\end{array}$ & -.0023306 & -.0054424 & -.0053402 \\
\hline EXPSOF & -.0257893 & .0318822 & -0.81 & 0.419 & $\begin{array}{l}\text { Failed to } \\
\text { reject }\end{array}$ & -.0071829 & -.0167734 & -.0164586 \\
\hline Cons & -.0591571 & .1230922 & -0.48 & 0.631 & $\begin{array}{l}\text { Failed to } \\
\text { reject }\end{array}$ & & & \\
\hline \multicolumn{2}{|c|}{ Number of obs $=384$} & \multicolumn{3}{|c|}{ Log likelihood = -32.979781 } & \multicolumn{3}{|c|}{221 uncensored observations } & \\
\hline \multicolumn{2}{|c|}{ LR chi2(15) = 748.01} & \multicolumn{6}{|c|}{ Prob $>$ chi2 $=0.0000$} & \\
\hline \multicolumn{2}{|c|}{ Pseudo R2 = 0.9190} & \multicolumn{6}{|c|}{163 left-censored observations at LOANRR $<=0$} & \\
\hline \multicolumn{9}{|c|}{ 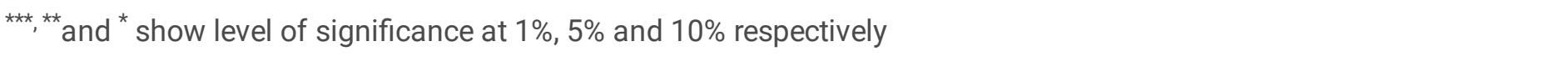 } \\
\hline \multicolumn{9}{|c|}{ Source: Own survey result (2020) } \\
\hline
\end{tabular}

Age of borrowers was found to be statistically significant factor of loan repayment rate (Table 4). As expected the age of the household head has a negative relationship with loan repayment rate and significantly influence at $1 \%$ level of significance, indicating that as the age of the respondents increases the loan repayment rate declines. This result implies 
that younger household heads could repay their loan when compared to their older fellow household heads. The result of the Tobit model showed that each additional year decreases the probability of being non-defaulter by $0.07 \%$ and the rate of repayment by $0.17 \%$ for the entire sample. This implies that a younger household heads most probably are flexible in nature and are ready to adapt new possibilities in building a good future for their family. Younger household heads are willing to work hard while facing adversity and can turn the situation around. While it is difficult sometimes at the old age to follow through hard work schedule or adjust to issues that may take a long period to be resolved. This result is consistent with finding of (Eyo et al., 2008; Hossain et al, 2019; Sangwan et al, 2020). This result is contracts with the works of Olagunju \& Adeyemo (2007), Reta (2011), and Wongnaa \& Awunyo-Vitor (2013), that reported age affects loan repayment rate positively and significantly. The authors further opined that older borrowers can better obey stated obligations than young people who have a high propensity to divert loan purposes to other uses (Baklouti, 2013; Enimu et al., 2017; Fentahun et al., 2018). Its implication is when the number of year's increase their honesties also increase due to religions afraid of God, the person to repay the loan, and also increases their work experiences.

The two limit estimates of the Tobit regression model presented in Table (4) showed that family sizes of borrowers is significantly and negatively related to the probability of loan repayment rate at $10 \%$ level of significance. This implies that as the number of borrowers' family increase in a household, their likelihood to repay their loan decreased. The implication is when the family size of borrowers become larger, many of the incomes produced by loan financed activities would be used for household consumption that leads to failure to repay the loan and gave a negative coefficient to loan repayment. As the result showed, each additional person to a family decreases the probability of being non-defaulter by $0.52 \%$ and decreases the rate of repayment by a factor of $1.21 \%$ for the entire borrowers (Table 4 ). This implies that for a borrowers who had large household size, a considerable amount of income from the business could be diverted away from loan repayment to household uses. In other words, for each additional dependent in the household, the probability of loan default increased. The result is consistent with the studies conducted by (Olagunju \& Adeyemo, 2007; Eyo et al., 2008; Roslon \& Karin, 2009; Sileshi, 2014; Auka \& Mwangi, 2014; Werema \& Opanga, 2016; Enimu et al., 2017; Fetnahun et al., 2018). While this result is inconsistent to Gebeyehu et al. (2013). This implies that an increase the family members, the more the labor force available for production purposes. Therefore, there is a possibility to have more alternative sources of income to overcome credit risks.

As expected, from the human capital-related variables, the results show that level of education among non-defaulter borrower households is higher on those who are defaulter and had a positive and significant effect on the loan repayment rate among rural farm households in the study area at less than $1 \%$ level of significance. The positive sign here indicates that when the level of education increases the loan repayment rate increases. The result shows that for a one-unit increase in the educational level of the respondents, the probability of being non-defaulter increase by a factor of $11.57 \%$ and increases the rate of repayment by a factor of $2.65 \%$ for the entire borrowers (Table 4 ). This proves the hypothesized role of education in raising the level of awareness, exposure to technologies, and information to borrowers. Higher education level may, thus, signify lower repayment risk (Sangwan et al, 2020). This result is consistent with the findings by Enimu \& Ohen (2017), Enimu et al. (2016), and Enimu et al. (2017). Thus, the clients with higher levels of education are more likely to have higher repayment rates (Werema \& Opanga, 2016).

Land size was hypothesized to influence loan repayment performance positively. As expected, the size of land size was found to influence the loan repayment rate of the borrowers positively and significantly at $1 \%$ level of significance. This implies that with increment in the size of landholding, borrowers would have the option to deliver more harvests and create more salary that would empower them to settle their debt. Each extra hectare of land was found to builds the likelihood of loan repayment (non-defaulter) by $10.68 \%$ and expands the rate of repayment by $24.48 \%$ for the whole borrowers (Table 4 ). This result is in accord with studies by Brehanu \& Tufa (2008). This implies that with increase in the size of land holding, farmers would be able to produce more crops and generate more income that would enable them settle their debt 
In this study, the results of the Tobit model revealed that livestock size affects loan repayment rate of borrowers positively. As hypothesized livestock size and loan repayment rate have positively and significantly related at a $10 \%$ level of significance. Each additional TLU increases the probability of being non-defaulter by $0.34 \%$ (Table 4 ). Also, for each additional unit of TLU the rate of loan repayment increases by $0.78 \%$ for the whole borrowers (Table 4 ). As it was initially hypothesized, this variable influenced the loan repayment rate of the respondent positively. This implies that borrowers who owned more livestock in terms of TLU were able to settle their debt on time even during crop production failure. The result is also supported by findings of Amare (2005), Brehanu \& Fufa (2008), Abebe (2011), Sileshi (2014), Auka \& Mwangi, (2014), and File \& Sori (2019). The implication is that, farmers who owned more livestock are able to repay their loans even when their crops fail due to natural disaster (Fentahun et al., 2018).

Getting income from non-farm activities is another economic factor that positively and significantly affected the loan repayment rate of small-holder farmers at $1 \%$ level of significance. This might be because non-farm activities were additional sources of income for small-holders and the cash generated from these activities could back up the farmers' income to settle their debt even during bad harvest seasons and when the repayment period coincided with low agricultural prices. Farmers' participation in non-farm activity increases the probability of being non-defaulter by $3.24 \%$ and for each additional income received from such activities, the rate of loan repayment on average increases by $7.58 \%$ for all respondents (Table 4). Possible reason is that borrowers who had other alternative source of income were found to better payers relative to those who didn't have other sources of income. This result is consistent with the study result of Amare (2005), Berhanu \& Fufa (2008), Medhin (2015), Fentahun et al. (2018), and File \& Sori (2019). Each additional income received from such activities increases the proportion of loan repayment among small-holder borrowers. However, this result is contrary to result obtained by Dorfleitner et al. (2016).

The purpose of borrowing is another economic factor that was positively and significantly influenced loan repayment rate of borrowers at $1 \%$ probability level. This may be because of the way that; small-holder farmers who utilized the loan for a productive purpose such as purchased agricultural inputs (chemical fertilizers and improved seeds) and livestock that produced enterprises that would give maximum benefits to the farmer. These farmers are the recipient of the utilization of loan that would build their pay capacity and repay their loans timely. Effective utilization of available loan for productive purpose increases the probability of being non-defaulter by $2.76 \%$ and on average increases the rate of loan repayment by $6.46 \%$ for the entire respondents (Table 4). The result of this study is supported by the result obtained File \& Sori (2019). While according to Werema \& Opanga (2016) loans granted to clients were not used for the intended primary objectives because some clients used the loans for consumption instead of production; therefore a small portion of loan received was then used to run their ongoing businesses.

The results of the Tobit model also revealed that road distance to the market center influenced loan repayment performance negatively. As hypothesized, road distance to the market center was found to be significant determinants of loan repayment rate at $1 \%$ significance level (Table 4). The negative sign indicates as borrower who are very near to the market center are more likely to be non-defaulters as compared to borrowers who are far from the market center. This is because borrowers who far from the market center are purely farmers and loans extended for an agricultural purpose which are expected to face the problem of default because of risk and uncertainty attached to agriculture. A one killo meter increases in road distance between the place of the borrowers and the market center, the probability a borrower to be nondefaulter decreases by $5.99 \%$ and on average the loan repayment rate declines by $14 \%$ for the whole respondents (Table 4 ).

The number of contact years that the household heads had with development agents is another significant institutional factor that strongly affected small-holder farmer's loan recovery, which was positively related to the dependent variable at $5 \%$ significance level for all the respondents. On average, one-year additional experience in the extension package increases the rate of loan repayment rate by $0.34 \%$ among non-defaulters and by $0.79 \%$ for the whole respondents, ceteris paribus (Table 4). This implies that contact with development agents was positively and significantly related to the loan repayment rate of the small-holder farmers. Farmers who have frequent contact with development agents are expected to

Page $17 / 27$ 
be better informed about markets and new production technologies that might have increased their income and help them to settle their debts timely as promised more than those who had less or no assistance at all (Berhanu \& Tufa, 2008; Fentahun et al., 2018; File \& Sori, 2019).

Delivering sufficient training on loan use for borrowers in the appropriate time has a positive contribution to the repayment rate. As hypothesized, the Tobit model result revealed that there is a significant positive association between training on loan use and loan repayment rate of borrowers at $1 \%$ level of probability (Table 4). If other variables held constant, delivering of organized and adequate training on loan use utilization properly for borrowers increases the probability of being non-defaulter by $16.73 \%$ and on average increased by $39.08 \%$ for the entire sample (Table 4 ). Similarly, the study by Karlan \& Valdivia (2011) and Lensink et al. (2011) revealed that entrepreneurship training may improve microbusiness performance and, therefore, loan repayment rates. While this result is inconsistent with the study results that showed training interventions fail to improve loan repayment rates, strikingly, clients monitoring does improve repayment rates, irrespective of the clients' educational level, business experience or gender (Agbeko et al., 2017).

\section{Conclusions And Recommendations}

This study analyzed factors affecting loan repayment rate from ACSI among smallholder farmers in Habru district, Ethiopia. The descriptive statistical analysis of study showed that there were $42 \%$ defaulter and $58 \%$ non-defaulter smallholder farmers respectively in the study area. In this study, the loan repayment rate of borrowers was taken as the primary way to group the borrowers into defaulters and non-defaulters. Accordingly, 221 out of 384 of the respondents were non-defaulters who were repaying the loan on time while 163 were defaulters. The econometric results obtained to go with somewhat towards establishing and clarifying relations between various independent variables and loan repayment rate of smallholder farmers in the study area. The result of two-limit Tobit econometric model indicated that, from a total of 15 explanatory variables considered in the regression model, 10 variables (age, family size, education level, land size, livestock size in TLU, non-farm income, the purpose of borrowing, road distance, contact with extension agent, training before taking loans) were found statistically significant influences on the loan repayment rate of the sample households in the study area.

The finding of this study revealed that the age of respondents negatively and significantly affects their loan repayment rate. The younger borrowers were found better to repay their loans than elder borrowers. However, this doesn't mean elder borrowers should be excluded from credit services. Instead, the institution should examine and understand the main reasons and challenges that the elder borrowers are facing to repay their loan timely to solve their problems through frequent follow-up, awareness creation, and formal trainings. This is because, on the contrary, there were different findings that reported age positively affects loan repayment. The findings revealed that older borrowers did not divert loan purposes to other uses as that of young borrowers. Its implication is as the number of year's increase their honesties and work experience may increases. According to this study, education level of borrowers affects loan repayment rate positively and significantly. This implies that as the level of education increases, borrowers enhance their ability to utilize loan effectively and efficiently. Therefore, as a level of education increases the overall awareness of borrowers will increases. Therefore, the institution should be given a due emphasis and do together with relevant government bodies so that all borrowers can access at least basic education and trainings to increase their loan repayment rate. In addition, Community education offices should provide adult learning program for illiterate small-holder farmers in the study area. In this study, family size significantly and negatively affects loan repayment rate of borrowers. Thus, special attention should be given by ACSI Habru branch credit department to borrowers who have a large family size. This attention can be made in terms of close follow-up and support on how to use loans, manage their business activities, and cash incomes incurred by loan financed activities. There are also arguments that found an increase the family members, the more the labor force available for production purpose. Therefore, there is a possibility to have more alternative sources of income to overcome credit 
The Tobit model result also found that land size affected loan repayment rate of borrowers positively and significantly. This is because those borrowers with larger land size earn more income from agricultural activities, which in turn helps them in loan repayment. The coefficient of the variable land size indicates that the probability of loan repayment rate increased with farm size at an increasing rate. Therefore, the lending institutions should not consider the size of the land as sufficient conditions to lend credit services for the small-holder farmers. This is because, farmers may obtain high income from a small size of land by applying modern technologies and inputs (technologies such as improved seeds, fertilizers, irrigation technologies, and etc). As result, the institution should collaborate with Agriculture offices to encourage smallholder farmers so as to intensify their small size of land by applying fertilizer and other modern inputs by accessing credit to improve their repayment performance. Large land size by itself doesn't mean high repayment rate and give guarantee for high repayment rate. The other finding of this study was that the livestock size in TLU affects the loan repayment rate of the borrowers positively and significantly. This infers the higher the quantity of livestock owned, the more the likelihood of being non-defaulter and the other way around. Therefore, to increase the loan repayment rate, improvements of the livestock production should be given emphasis through the provision of livestock extension services such as animal genetic resources improvement; feed resources improvement and management, control and prevention of animal diseases and parasites, and development of marketing facilities These would help to increase income of the borrowers thereby reducing defaults on borrowed funds.

Non-farm income has also positively and significantly affects the loan repayment rate of smallholder farmers in the study area. As the result indicated, income from other diversified sources is more helpful for borrowers to repay their loan on time. Therefore, the institution should encourage and create awareness to all borrowers to participate and diversify their income sources on non-farm income-generating activities. The model result also revealed that the variable purpose of borrowing affects loan repayment rate positively. This is because, if the borrower utilizes their loans for the intended purpose, there is a possibility that the repayment rate of the borrowers can settle their loan timely. Therefore, to increase the loan repayment rate, institution should provide continuous follow-up and technical support to all borrowers to use their loans for the intended purposes. In this study, number of contacts of the borrowers with agricultural extension agents was positively related to the dependent variable loan repayment rate significantly. This might because those farmers who have contact with development agents can easily get knowledge and skills that will help them to effectively utilize and manage their business in a profitable manner and to make conscious decision to repay loan timely. Therefore, awareness creation should be given by institution to increase extension contacts of all borrowers to effectively use their loan and change the farmers' attitude toward the timely settlement of the debt.

Moreover, the results of the Tobit model found that road distance between the market center and the borrowers' place of residence had a significant negative impact on loan repayment rate of the small-holder farmers. In other words, borrowers who live very near to the market center were found to be better in repaying loans. This implies that the one who live near to the market center was to be pay loan on time since market access increases probability of the success of the business. Therefore, the government should relocate the small-holder borrowers near to the market centers or if necessary form new markets centers nearby their residences. The result of this study also revealed that training received on loan use affects the loan repayment rate of the small-holder farmers positively and significantly. The result pointed out that, those household heads who received training are more likely to become non-defaulter than the household heads with not getting training. Therefore, institution should give training on basic business ideas and management and saving cultures to provide a basic understanding of credit management on a daily basis and create profitable creditworthy borrowers in the study area. In summary, future researches should be carried out with higher number of samples to highlight the influence of other factors on loan repayment behavior of borrowers and validate the empirical and theoretical accuracy of this study to make sure the sustainability of the institution in the study area.

\section{Declarations}




\section{Competing Interests}

The authors declare that they have no competing interests.

\section{Authors' Contributions}

All authors write, read, and approved the manuscript equally.

\section{Funding}

This research did not receive any specific grant from funding agencies in the public, commercial, or not-for-profit sectors.

\section{References}

1. Abebe, M. (2011). Determinants of Credit Repayment and Fertilizer Use by Cooperative Members in Ada District, East Shoa Zone, Oromia Region. M.Sc. Thesis, Haramaya University, Ethiopia. Available at: https://cgspace.cgiar.org/handle/10568/68993

2. Abera, N., \& Asfaw, M. (2019). Impact of Microfinance on Rural Household Poverty in Ethiopia. Journal of Ecology \& Natural Resources, 3(5), 1-11. doi: 10.23880/jenr-16000177 10127771

3. Abu, B. M., Domanban, P. B., \& Issahaku, H. (2017). Microcredit Loan Repayment Default among Small Scale Enterprises: A Double Hurdle Approach. Ghana Journal of Development Studies, 14(1), 146-165. doi.org/10.4314/gjds.v14i1.8

4. ACSI. (2016). Annual Report. Habru district, Unpublished.

5. AfDB. (2012). The Five-Year Growth and Transformation Plan (GTP), of Ethiopia: African Economic Outlook.

6. Afolabi, J.A. (2010). Analysis of loan repayment among farmers in Oyo State Nigeria. Journal of Social Sciences, 22(2), 115-119, doi: 10.1080/09718923.2010.11892791

7. Agbeko, D., Blok, V., Omta, S.W.F., \& Van der Velde, G. (2017). The impact of training and monitoring on loan repayment of microfinance debtors in Ghana. Journal of Behavioral and Experimental Finance, 1-17. .doi.org/10.1016/j.jbef.2017.03.002

8. Alemayehu, M., \& Lemma, M. (2014). Assessment of Factors Affecting the Performance of Microfinance Institutions: The Case of Hawassa City. Journal of the British Astronomical, 6(1), 1-47.

9. Allen, F., Demirguc-Kunt, A., Klapper, L., \& Martinez-Peria, M.S. (2012). Policies to expand financial inclusion. In: Development research group. The World Bank, Washington D.C

10. Amare, B. (2005). Determinants of formal source of credit, loan repayment performance of smallholder farmers: The case of North Western Ethiopia, North Gondar (M.Sc. Thesis). Alemaya University, Ethiopia.

11. Amemiya, T. (1973). Regression Analysis when the Dependent Variable Is Truncated Normal. Econometrica, 41(6), 997-1016. URL: http://www.jstor.org/stable/1914031

12. Anyiro, C. O., \& Oriaku, B. N. (2011). Access to and Investment of Formal Micro Credit by Small Holder Farmers in Abia State, Nigeria. A Case Study of Absu Micro Finance Bank, Uturu. Journal of Agricultural Sciences, 6(2), 69-76.

13. Asiama, R. K., \& Amoah, A. (2019). Non-performing loans and monetary policy dynamics in Ghana. African Journal of Economic and Management Studies, 10(2), 169-184. https://doi.org/10.1108/AJEMS-04-2018- 0103

14. Auka, D.O., Mwangi, J.K. (2014). Factors Influencing Sacco Members to Seek Services of Other Financial Service Providers in Kenya. International Review of Management and Business Research, 2(2), 610-622. 
15. Baidoo, S.T., Yusif, H., \& Ayesu, E.K. (2020). Improving

Ioan repayment in Ghana: Does financial literacy matter? Cogent Economics \& Finance, 8(1), 1-20. doi: 10.1080/23322039.2020.1787693

16. Baidu-Forson, J. (1999). Factors influencing adoption of land-enhancing technology in the Sahel: lessons from a case study in Niger. Agricultural economics, 20 (3), 231-239. doi:10.1111/j.1574-0862.1999.tb00569.x

17. Baklouti, I. (2013). Determinants of microcredit repayment: The case of Tunisian Microfinance Bank. African Development Review, 25(3), 370-382. doi:10.1111/j.1467-8268.2013.12035.x

18. Banerjee, A., Duflo, E., Glennerster, R., Kinnan, C. (2014). The Miracle of Microfinance? Evidence from a Randomized Evaluation, working paper. MIT Department of Economics.

19. Becker, G. S. (1993). Nobel lecture: The economic way of looking at behavior. Journal of political economy, 101(3), 385-409.URL: https://www.jstor.org/stable/2138769

20. Brehanu, A., \& Fufa, B. (2008). Repayment rate of loans from semi-formal financial institutions among small-scale farmers in Ethiopia: Two-limit Tobit analysis. The Journal of Socio-Economics, 37, 1-

10. doi:10.1016/j.socec.2008.02.003

21. Brett, C. (2004). Farm level adoption decisions of soil water management technologies in Semi-Arid Eastern Kenya. In: Contributed Paper Presented at the 48th Annual Conference of the Australian Agricultural and Resource Economics Society, 11-13th February, 2004, Melbourne, Victoria. Available at: https://core.ac.uk/download/pdf/6517728.pdf

22. Cochran, W. G. (1963). Sampling Techniques, $2^{\text {nd }}$ Ed., New York: John Wiley and Sons, Inc.

23. Deribie, E., Nigussie, G., \& Mitiku, F. (2013). Filling the breach: Microfinance. Journal of Business and Economic Management, 1(11), 10-17

24. Dorfleitner, G., Just-Marx, S., \& Priberny, C. (2016). What drives the repayment of agricultural micro loans? Evidence from Nicaragua. The Quarterly Review of Economics and Finance, 1-37. doi:10.1016/j.qref.2016.02.009

25. Dwight, M.J. (1971). Credit Rationing and the Commercial Loan Market. The Journal of Finance, 24(4), 729. URL: http://www.jstor.org/stable/2326234

26. Enimu, S., Eyo, E.O., \& Ajah, E.A. (2017). Determinants of loan repayment among agricultural microcredit finance group members in Delta state, Nigeria. Financial Innovation, 3(21), 1-12. doi: 10.1186/s40854-017-0072-y

27. Enimu, S., Igiri, J., \& Achike, A.I. (2016) Analysis of the effects of microfinance banks loans on the livelihood of smallholder farmers in Delta state, Nigeria. Journal of economic Affairs, 61(3), 381-390. doi: 10.5958/09764666.2016.00049.8

28. Enimu, S., Ohen, S.B. (2017) Effect of membership homogeneity on the design and performance of formal agricultural microcredit finance groups in Delta state, Nigeria. Journal of Agricultural Economics, Extension and Rural. Development, 5(6)-649-657. Available at: https://www.academia.edu/33813198

29. Eyo, E.O., Out, J.O., \& Sampson, M.G. (2008). Homogeneity in group membership social characteristics and loan recovery: implications for success of formal-informal sector linkage in Akwa-lbom state, Nigeria. The Social Sciences, 3(1), 17-22. doi: sscience.2008.17.

30. Fentahun, G.E., Kefale, D., \& Ahmed, Y. (2018). Determinants of Smallholder Farmers Loan Repayment Performance in Assosa District, Western Ethiopia. Journal of Economics and Sustainable Development, 9(5), 46-57.

31. File, A., \& Sori, O. (2019). Determinants of Loan Repayment Performance of Smallholder Farmers in Horro and Abay Choman woredas of HoroguduruWollega Zone, Oromia Region, Ethiopia. Journal of Agricultural Economics and Rural Development, 5(3), 648-655. Available at: https://www.premierpublishers.org/ajaerd/261120199063

32. Freimer, M., \& Gordon, M.J. (1965). Why Bankers Ration Credit, The Quarterly Journal of Economics, 79(3), 397416. doi:10.2307/1882705

Page $21 / 27$ 
33. Garomsa, A. (2017). Assessment of Factors Affecting Loan Repayment Performance of Borrowers: An Empirical Study on Selected Microfinance Institutions in Oromia Region. A Thesis Submitted to College of Business and Economics, Department of Accounting and Finance, Addis Ababa University. Unpublished

34. Gebeyehu, Z., Beshir, H., \& Haji, J. (2013). Determinants of Loan Repayment Performance of Smallholder Farmers: The Case of Kalu District, South Wollo Zone, Amhara National Regional State, Ethiopia. International Journal of Economics, Business and Finance, 1(11), 431- 446. Available at: http://ijebf.com/

35. Gujarati, D.N. (2007). Basic econometrics. $4^{\text {th }}$ Edition. Mc Graw-hill, Inc. New York.

36. HDARDO. (2020). Habru District Agricultural and Rural Development Office annual report, unpublished.

37. HDCAO. (2020). Habru District Chief Administration Office Annual Report, 2019.

38. Hossain, S. M., Sarker, M., Nazneen, S., Basu, B., Rasul, F.B., \& Adib, H.I. (2019). How health shocks and its relationship to repayments of loans from microfinance institutions can affect migrant households in Bangladesh. Migration and Development, 8(3), 1-24. doi:10.1080/21632324.2019.1565088

39. Huppi, M., \& Feder, G. (1990). The role of groups and credit cooperatives in rural lending. World Bank Research Observer, 5(2), 187-204. doi: 10.1093/wbro/5.2.187

40. Ibtissem, B., \& Bouri, A. (2013). Credit Risk Management in Micro-Finance: the conceptual framework. ACRN Journal of Finance and Risk Perspectives, 2(1), 9 - 24. Available at: www.acrn.eu/resources/Journals/jfrp201301b.pdf

41. Jarrow, R., \& Protter, P. (2004). Structural versus reduced form models: a new information based perspective, Journal of Investment Management, 2(2), 1-10. doi:10.1002/9781119201892.ch6

42. Johnston, J., \& Dinardo, J. (1997). Econometrics Methods. Fourth Edition. The McGraw-Hill Companies, Inc, New York.

43. Jote, G. G. (2018). Determinants of Loan Repayment: The Case of Microfinance Institutions in Gedeo Zone, SNNPRS, Ethiopia. Universal Journal of Accounting and Finance, 6(3), 108-122. doi: 10.13189/ujaf.2018.060303

44. Karlan, D., \& Valdivia, M. (2011). Teaching Entrepreneurship: Impact of Business Training on Microfinance Clients and Institutions. Review of Economics and Statistics, 93(2), 510-527. doi: Doi 10.1162/Rest_a_00074

45. Kebede, G. (2018). The Trend of Loan Recovery Performance in Banking Industry: A Case Study of Oromia International Bank S.C.A. Thesis Submitted to School of Graduate Studies in In Accounting and Finance, St. Mary's University. Unpublished

46. Keenan, S. (1999). Historical default rates of corporate bond issuers 1920-1998, Moody's Investor Service, Global Credit Research, January 1999.

47. Kim, B., \& Maddala, G. (1992). Estimation and Specification Analysis of Models of Dividend Behavior Based on Censored Panel Data. Empirical Economics, 17(1), 111-124. doi:10.1007/bf01192478

48. Kinde, A. B. (2012). Financial Sustainability of Microfinance Institutions (MFIs) in Ethiopia. European Journal of Business and Management, 4(15), 1-11.

49. Kraiger, K., Ford, J. K., \& Salas, E. (1993). Application of cognitive, skill-based, and affective theories of learning outcomes to new methods of training evaluation. Journal of applied psychology, 78(2), 311-328. doi: 10.1037/00219010.78.2.311

50. Lapar, M. L., \& Graham, D. (1988). Credit Rationing Under a Deregulated Financial System. A Paper Presented at the Workshop: Financial Intermediation in the Rural Sector Research Results and Policy Issues" held at the Central Bank, Manila on 26-27 September 1988. Available at: https://core.ac.uk/download/pdf/159586953.pdf

51. Lensink, R., Mersland, R., \& Nhung, V. T. H. (2011). Should microfinance institutions specialize in financial services? Paper presented at the second international research conference on microfinance, Groningen, The Netherlands.

52. Lopatta, K., Tchikov, M., Jaeschke, R., \& Lodhia, S. (2017). Sustainable Development and Microfinance: The Effect of Outreach and Profitability on Microfinance institutions'. Development Mission. Sustainable development, doi: 
10.1002/sd.1663

53. Lynne, G.D., Shonkwiler, J.S., \& Rola, L.R. (1988). Attitudes and Farmer Conservation Behavior. American Journal of Agricultural Economics, 70(1):12-19. doi:10.2307/1241971

54. Mcdonald, J. F., \& Moffitt, R. A. (1980). The Uses of Tobit Analysis. Review of Economics and Statistics, 6(2), $318-321$. doi:10.2307/1924766

55. Medhin M, (2015) Determinants of Loan Repayment Performance of Rural Women Based Saving and Credit Cooperatives' Members: The Case of Dire Dawa Administration. Available at: https://www.academia.edu/16291257/Determinants_of

56. Melese, M. \& Asfaw, M. (2020). Determinants of Loan Repayment Performance of Omo Microfinance Institution: In the Case of Mizan Aman Town, Southwest Ethiopia. Research Journal of Business Management, 14. doi:10.3923/rjbm.2020.7.14

57. Melkamu, T. (2012). Determinants of Operational and Financial Self-Sufficiency: An Empirical Evidence of Ethiopian Microfinance Institutions. MSc thesis, Addis Ababa University, Addis Ababa Ethiopia. Unpublished.

58. Million, S., Nyikal, R., \& Wangia, S. (2014). Factors Affecting Loan Repayment Performance of Smallholder Farmers in East Hararghe, Ethiopia. The journal of Developing Country Studies, 11(2), 205-213.

59. Mohammad, R, (2009). Factors affecting on loan repayment performance of farmers in Khorasan-Razavi province of Iran. A Paper Presented to the Conference on International Research on Food Security, Natural Resource Management and Rural Development. Mashhad, Iran.

60. Nuryartono, N., Zeller, M., \& Schwarze, S. (2005). Credit Rationing of Farm Households and Agricultural production: Empirical Evidence in the Rural Areas of Central Sulawesi, Indonesia. Conference on International Agricultural Research for Development Stuttgart-Hohenheim, October 11-13, 2005. Available at: https://mpra.ub.unimuenchen.de/31815

61. Okurut, F. N., S. Ssewanyana., J.J.A.O. Odwee., \& Asaf Adebua. (2006). Poverty and Labour market response in the context of economic reforms in Uganda, 1992-2003, a progress report submitted to the African Economic Research Consortium (AERC).

62. Olagunju, F.I, \& Adeyemo, R. (2007). Determinants of repayment decision among small-holder's farmers in Ogbomosho agricultural zone of Oyo state, Nigeria. Journal of Social Science, 4(5):677-686. doi:

10.1080/09718923.2008.11892634

63. Olokoyo, F.O. (2011). Determinants of Commercial Banks' Lending Behavior in Nigeria. International Journal of Financial Research, 2(2), 61-72. doi:10.5430/ijfr.v2n2p61

64. Pasha, S. A. M., \& Negese, T. (2014). Performance of Loan Repayment Determinants in Ethiopian Micro Finance - An Analysis. Eurasian Journal of Business and Economics, 7(13), 29-49. Available at:

https://www.ejbe.org/EJBE2014Vol07No13p029PASHA-NEGESE.pdf

65. Ployhart, R. E., \& Moliterno, T. P. (2011). Emergence of the human capital resource: A multilevel model. Academy of Management Review, 36(1), 127-150. doi: 10.5465/amr.2009.0318

66. Reta, F. K. (2011). Determinants of loan Repayment Performance: A case study in the Addis Credit and Saving Institution, Addis Ababa, Ethiopia. Submitted in Partial Fulfillment of the Requirements for the Degree of Master's in Management, Economics and Consumer Studies, 1-72. Unpublished.

67. Rosett, R.N., \& Nelson, F. D. (1975). Estimation of the Two-Limit Probit Regression Model. Journal of the econometric society, 43 (1), 141-146. doi: 10.2307/1913419

68. Sangwan, S., Nayak, N.C., \& Samanta, D. (2020). Loan repayment behavior among the clients of Indian microfinance institutions: A household-level investigation. Journal of Human Behavior in the Social Environment, 1-24. doi:

$10.1080 / 10911359.2019 .1699221$

Page 23/27 
69. Schervish, M.J. (1995) Theory of Statistics. Springer, New York. Open Journal of Statistics, 4(5). doi 10.1007/978-14612-4250-5

70. Shimelles, T., \& Zahidul Islam K.M. (2009). Rural financial services and effects of microfinance on agricultural productivity and on poverty: Discussion Papers No: 37, University of Helsinki Department of Economics and Management, Helsinki

71. Sileshi, C. (2014). Loan Repayment Performance of Farm Households: The Case of Omo Microfinance in Soddo Zuria District of Southern Ethiopia. A Thesis Submitted to the School of Agricultural Economics and Agribusiness, School of Graduate Studies, Haramaya University. Unpublished

72. Sileshi, M., Nyikal, R., \& Wangia, S. (2012). Factors Affecting Loan Repayment Performance of Smallholder Farmers in East Hararghe, Ethiopia. Developing Country Studies, 2, 205-213.

73. Smith, D. A., \& Brame, R. (2003). Tobit Models in Social Science Research. Some Limitation and a More General Alternative. Sociological Methods and Research, 31(3), 364-388. doi:10.1177\%2F0049124102239080

74. Stigliz, J.Z. \& Weiss, A. (1981). Credit rationing in markets with imperfect information. American Economic Review, 71 (3), 393-410. URL: https://www.jstor.org/stable/1802787

75. Storck, H., Emana, B., Adenew, B., Borowiecki, A., \& Wolde-Hawaria, S. (1991). Farming Systems and Farm Management Practices of Smallholders in the Harerghe Highlands-a Baseline Survey Farming Systems and Resource Economics in the Tropics. Kiel, Germany: Wissenschaftsver lag Vauk, Kiel, Germany, 11, 41-48.

76. Sunday, E., M. \& Anthonia, A. I. (2017). Analysis of Loan Acquisition and Repayment among Small Scale Rice Farmers in Ebonyi State, Nigeria: Implication for Effective Credit Delivery. Journal of Economics and Finance, 8(3), 20-26. doi: 10.9790/5933-0803012026

77. Tarekegn, A. \& Molla, T. (2018). The Paradox of Poverty Reduction in Ethiopia: Are Microfinance Institutions Really Propoor? Asian Journal of Economics, Business and Accounting, 8, 1-7. doi:10.9734/AJEBA/2018/44597

78. Tobin, J. (1958). Estimation of Relationships for Limited Dependent Variables. Econometrica 26(1), 24-36. doi:10.2307/1907382

79. Tobit, J. (1956). The Review of Economics and Statistics. The MIT Press, 38(3), 241-247. doi: 10.2307/1925776

80. Ume, S. I., Ezeano, C. I., \& Obiekwe, N. J. (2018). Analysis of Determinant Factors to Loan Repayment among Broiler Farmers in Enugu State, Nigeria. International Journal of Environmental \& Agriculture Research, 4(6), 1-11. Available at: https://www.academia.edu/37422806

81. Wenner, M. D. (2015). Group Credit: A Menace to Improve Information Transfer and Loan Repayment Performance. Journal of Development Studies, 32 (2), 263- 281. doi: 10.1080/00220389508422414

82. Werema, S., \& Opanga, K. (2016). Factors Affecting Clients On Loan Repayment For Microfinance Institutions: A Case Study of Pride Arusha, Tanzania. International Journal of Scientific and Technical Research in Engineering, 1(8), 34-41. Available at: www.ijstre.com/Publish/112016/371428286.pdf

83. Wongnaa C. A., \& Awunyo-Vitor, D. (2013). Factors affecting loan repayment performance among Yam farmers in the Sene district, Ghana. Agris on-line Papers in Economics and Informatics, 5(2), 111-122.

84. Wooldridge, J. M. (2016). Introductory econometrics a modern approach (4 ${ }^{\text {th }}$ ed.). Mason: South Western Cengage Learning

85. Yibrie, O., \& Ramakrishna, R. (2017). Determinants of Loan Repayment Performance in ACSI. International Journal of Advanced Research in Management and Social Sciences, 6, 151-170.

86. Yimer, G. (2019). Determinants of Amhara Credit \& Saving Institution (ACSI) Loan Repayment Performance: A case of Jawi Branch. A Thesis Submitted in partial fulfillment of the requirement for the Degree of Master of Science in Accounting and Finance, 1-106.

87. Zeller, M. (1998). Determinants of Repayment Performance in Credit Groups: The Role of Program Design, Intra group Risk Polling and Social Cohesion. International Food Policy Research Institute. Reprint No. 384.

Page 24/27 
88. Zerai, B., \& Rani, L. (2012). Technical efficiency and its determinants of micro finance institutions in Ethiopia: A stochastic frontier approach, African Journal of Accounting, Economics, Finance and Banking Research, 8(8), 1-29. Available at: globip.com/contents/articles/african-vol8-article1.pdf

\section{Table}

\section{Table 1}

Type, Definition, Measurement and Working Hypothesis of Independent Variables

\section{Figures}

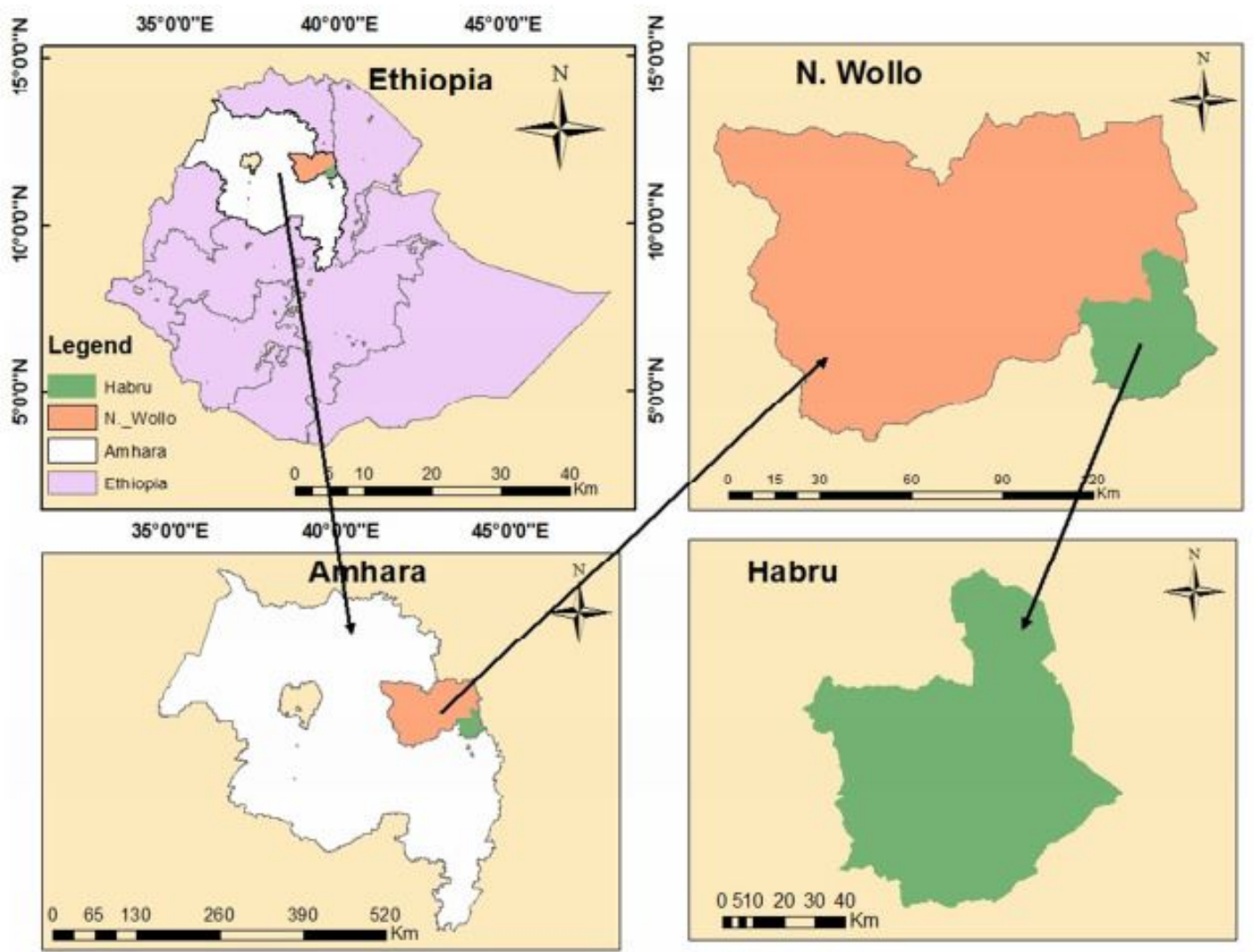

Figure 1

Map of the study area 


\begin{tabular}{|c|c|c|c|}
\hline Variables & Type and Definitions & Measurement & Hypothesis \\
\hline $\begin{array}{l}\text { Dependent } \\
\text { variables }\end{array}$ & Continuous, loan repayment rate & $1=$ Non defaulter, $0=$ defaulter & \\
\hline \multicolumn{4}{|l|}{$\begin{array}{l}\text { Independent } \\
\text { Variables }\end{array}$} \\
\hline \multicolumn{4}{|l|}{$\begin{array}{l}\text { 1. Demographic } \\
\text { characteristics }\end{array}$} \\
\hline Sex & Dummy, sex of the small-holder farmer & $1=$ Male, $0=$ Female & $+/-$ \\
\hline Age & Continuous, age of small-holder farmer & $\begin{array}{l}\text { years of the age of the small- } \\
\text { holder farmer }\end{array}$ & $-/+$ \\
\hline Family size & $\begin{array}{l}\text { Continuous, total number of the family of small- } \\
\text { holder farmer }\end{array}$ & $\begin{array}{l}\text { Number of persons living } \\
\text { under one roof }\end{array}$ & $-/+$ \\
\hline $\begin{array}{l}\text { Educational } \\
\text { level }\end{array}$ & $\begin{array}{l}\text { Continuous, number of years of school attained } \\
\text { by the small-holder farmer up to the time of the } \\
\text { survey }\end{array}$ & In Years & + \\
\hline $\begin{array}{l}\text { 2. Socio- } \\
\text { economic } \\
\text { characteristics }\end{array}$ & & & + \\
\hline Land size & $\begin{array}{l}\text { Continuous, total cultivated farm size owned by } \\
\text { smallholder farmer }\end{array}$ & In Hectare & + \\
\hline Livestock size & $\begin{array}{l}\text { Continuous, total number of livestock owned by } \\
\text { the small-holder farmer }\end{array}$ & In TLU & + \\
\hline $\begin{array}{l}\text { Income from } \\
\text { non-farm } \\
\text { activities }\end{array}$ & $\begin{array}{l}\text { Continuous, participation of small-holder farmer } \\
\text { on non-farm income } \\
\text { employment } \\
\text { in non-farm activities by the household }\end{array}$ & $1=$ yes, $0=$ No & + \\
\hline $\begin{array}{l}\text { Purpose of } \\
\text { borrowing: }\end{array}$ & $\begin{array}{l}\text { Dummy variable, purpose of borrowing by small- } \\
\text { holder farmer }\end{array}$ & $\begin{array}{l}1=\text { Productive } 0=\text { Non- } \\
\text { productive }\end{array}$ & + \\
\hline \multicolumn{4}{|l|}{$\begin{array}{l}\text { 3. Institutional } \\
\text { Factors }\end{array}$} \\
\hline Road distance & $\begin{array}{l}\text { Continuous, the distance between the small- } \\
\text { holder farmer's residence and the market center }\end{array}$ & In kilometers & + \\
\hline $\begin{array}{l}\text { Contact with } \\
\text { development } \\
\text { agents }\end{array}$ & $\begin{array}{l}\text { Continues, the number of years a small-holder } \\
\text { farmer contacted a development agent }\end{array}$ & $\begin{array}{l}\text { Measured in years of } \\
\text { extension package experience }\end{array}$ & + \\
\hline Credit service & $\begin{array}{l}\text { Dummy, the source of credit to the small-holder } \\
\text { farmer in the study area. }\end{array}$ & $1=\mathrm{ACSI}, 0=$ Informal sector & + \\
\hline Loan amount & $\begin{array}{l}\text { Continuous, volume of loan obtained by a small- } \\
\text { holder farmer }\end{array}$ & ETB & + \\
\hline $\begin{array}{l}\text { Training on } \\
\text { loan use }\end{array}$ & $\begin{array}{r}\text { Dummy, training received by small-holder farmer } \\
\text { before and after taking }\end{array}$ & $1=$ Received, $0=$ Not received & $+/-$ \\
\hline
\end{tabular}

Page 26/27 
loans

Availability of

business

Dummy, availability of business information by

$1=$ yes, $0=$ No

$+$

information

the small-holder farmer before starting a

business

4. Cultural

Factors

Expenditure on

Continuous, it representing expenditure in birr on

celebrations by the small-holder farmer

Measures the amount of

expenditure in Birr 